Jurnal Akuntansi Bisnis, Vol. 19, No. 2, September 2021 ISSN 1412-775X (media cetak) | 2541-5204 (media online)

\title{
Kinerja Perusahaan: Pengaruh Corporate Social Responsibility dan Pertumbuhan Pendapatan
}

\author{
Anita $^{1^{*}}$, Dewi Anggreni ${ }^{2}$ \\ ${ }^{1,2}$ Universitas Internasional Batam \\ *Corresponding author email: anita.lec@uib.ac.id
}

\begin{abstract}
Indonesia is currently being hit by the coronavirus disease 2019 (COVID-19-19) pandemic, making the level of competition between companies more competitive to generate profits. This strongly encourages companies to look for ways to attract investors' attention in capital market. The purpose of this study is to analyse the effect of corporate social responsibility (CSR) disclosure and revenue growth on the firm performance of sustainable companies listed on the Indonesia Stock Exchange (IDX). This study will examine whether there is a relationship between CSR disclosure in sustainability reports and revenue growth on firm performance. CSR is measured by GRI-Standards. Firm performance is measured by return on assets (ROA), return on equity (ROE), return on invested capital (ROIC), and economic value added (EVA). A sample of 37 companies was obtained from purposive sampling method, in which companies listed on IDX must completely published sustainability reports during the 2016-2020 period. The analysis technique with panelbased data regression. The results of this research show that CSR disclosure in sustainability reports has a significant positive effect on firm performance (EVA). Revenue growth in sustainable companies also has a significant positive effect on firm performance (ROE).
\end{abstract}

\section{Keywords: Sustainable companies, corporate social responsibility, CSR disclosure, revenue growth, firm performance.}

\begin{abstract}
Abstrak
Indonesia saat ini tengah dilanda pandemi coronavirus disease 2019 (COVID-19), membuat tingkat persaingan antar perusahaan semakin kompetitif untuk menghasilkan laba. Hal ini mendorong secara keras perusahaan untuk mencari cara agar menarik perhatian investor di pasar modal. Tujuan penelitian ini untuk menganalisis pengaruh pengungkapan corporate social responsibility (CSR) dan pertumbuhan pendapatan terhadap kinerja perusahaan pada perusahaan berkelanjutan yang terdaftar di Bursa Efek Indonesia (BEI). Penelitian ini akan menguji apakah terdapat keterkaitan hubungan antara pengungkapan CSR di laporan keberlanjutan dan pertumbuhan pendapatan perusahaan terhadap kinerja perusahaan. CSR diukur dengan GRIStandards. Kinerja perusahaan diukur dengan rasio return on assets (ROA), return on equity (ROE), return on invested capital (ROIC), dan economic value added (EVA). Sampel sejumlah 37 perusahaan didapat dari penggunaan metode purposive sampling, di mana perusahaan yang terdaftar di BEI harus lengkap menerbitkan laporan keberlanjutan selama periode 2016-2020. Teknik analisis dengan regresi data berbasis panel. Hasil penelitian memperlihatkan bahwa pengungkapan CSR di laporan keberlanjutan berpengaruh signifikan positif terhadap kinerja (EVA). Pertumbuhan pendapatan pada perusahaan berkelanjutan mempengaruhi secara signifikan positif terhadap kinerja perusahaan (ROE).
\end{abstract}

Kata kunci: Perusahaan berkelanjutan, corporate social responsibility, pengungkapan CSR, pertumbuhan pendapatan, kinerja perusahaan. 
Jurnal Akuntansi Bisnis, Vol. 19, No. 2, September 2021

ISSN 1412-775X (media cetak) | 2541-5204 (media online)

\section{PENDAhuluan}

Setiap perusahaan pasti memiliki tujuan yang harus dicapai, salah satunya memenuhi kepentingan para pemangku kepentingan (stakeholder), yaitu dengan memperoleh profit sebesarbesarnya (Pan et al., 2014). Teori stakeholder mengatakan bahwa suatu perusahaan bertanggung jawab atas keseluruhan pihak yang berkepentingan di perusahaan (Supriyadi et al., 2019). Kinerja perusahaan yang baik sangat mempengaruhi kemajuan (Sari dan Andreas, 2019), kelancaran dan potensi dari jalannya proses bisnis perusahaan (Bodhanwala dan Bodhanwala, 2018). PT Total Bangun Persada Tbk misalnya, di mana pada awal tahun 2020 sampai kuartal-III lalu, perusahaan terus mendapati penurunan laba akibat ditundanya beberapa proyek di masa pandemik COVID-19 (Soenarso, 2020). Penurunan kinerja akibat COVID-19 juga banyak dialami oleh perusahaan dari berbagai sektor, seperti PT Indofood Sukses Makmur Tbk (Idnfinancials.com, 2020), PT Garuda Indonesia Tbk (Faqir, 2019), PT Satria Mega Kencana Tbk (Laodi, 2020), PT Pertamina (Handoyo, 2021), PT Rukun Raharja Tbk (Marketnews.id, 2021), PT Astra International Tbk (Amanda, 2021), PT Adhi Karya (Persero) Tbk (Sandria, 2021), dan lainnya. Permasalahan tersebut menunjukkan pentingnya kinerja yang baik bagi progress bisnis perusahaan.

Penurunan pada kinerja memperlihatkan bahwa investor saat ini juga memperdulikan peningkatan investasi dengan penerapan bisnis yang berkelanjutan (Liputan6.com, 2020). Pelaku bisnis dan investor tentunya menyadari bahwa dengan perusahaan menjalankan praktik keberlanjutan dapat membawa dampak baik terhadap kinerja. Hal ini terlihat dari banyaknya perusahaan yang menerbitkan laporan keberlanjutan di tahun 2020 untuk pertama kalinya. Semakin pentingnya keberlanjutan saat ini hingga membuat PT Garuda Indonesia Tbk memalsukan data CSR di laporan keberlanjutan agar terlihat bagus (Faqir, 2019). Maka dari itu, setiap perusahaan harus memiliki strategi sustainable development untuk mendorong dan mempengaruhi nilai operasional secara jangka panjang (Prasetyo, 2020), sehingga mengarah pada profit (keuntungan) yang lebih baik lagi ke depannya (Bodhanwala dan Bodhanwala, 2018).

Keberlanjutan merupakan ukuran dampak perusahaan pada bidang ekonomi, lingkungan, serta sosial yang ada pada masyarakat dan lingkungan perusahaan. Di Indonesia, isu keberlanjutan menjadi tuntutan penting yang wajib diperhatikan saat ini oleh perusahaan dan pelaku bisnis, terutama keadaan Indonesia yang sedang berada pada proses pemulihan dari pandemik COVID19 sekarang (Liputan6.com, 2020). Perubahan-perubahan sosial juga telah banyak terjadi dalam beberapa tahun terakhir ini, seperti iklim dan polusi (Centre For Risk Management \& Sustainability Indonesia, n.d.), dan kini COVID-19. Kerusakan pada lingkungan juga termasuk permasalahan yang sangat serius (Syafrullah dan Muharam, 2017), seperti perbuatan merusak lingkungan yang dilakukan oleh PT Garudafood Putra Putri Jaya Tbk, PT Indofood Sukses Makmur Tbk, dan PT Wings Surya tahun 2020 lalu (Idnfinancials.com, 2020). Maka dari itu, konsep keberlanjutan menjadi sorotan utama saat ini di seluruh dunia (Zhao et al., 2018), guna memperbaiki kondisi dunia yang sedang di masa kritis.

Beragam pasar bursa saham di seluruh dunia juga telah meluncurkan peraturan pedoman terkait pengungkapan keberlanjutan untuk perusahaan terdaftar di negara tersebut, seperti India, Korea Selatan, Malaysia, Inggris, China, Afrika Selatan, Thailand, Filipina, Singapura dan lainnya 
Jurnal Akuntansi Bisnis, Vol. 19, No. 2, September 2021 ISSN 1412-775X (media cetak) | 2541-5204 (media online)

(Zhao et al., 2018). Konsep keberlanjutan perusahaan dapat dilaksanakan dengan melakukan kegiatan tanggung jawab sosial (Velte, 2017), sebagai bentuk tindakan pertanggungjawaban meminimalkan setiap konsekuensi negatif yang terjadi terhadap masyarakat, dan pihak berkepentingan di perusahaan (Supriyadi et al., 2019). CSR sendiri di Indonesia telah diatur dalam Undang-Undang Nomor 40 Tahun 2007 terkait Tanggung Jawab Sosial Perusahaan dari tahun 2007 silam hingga sekarang (Syamni et al, 2018).

Perbincangan terkait CSR (ekonomi, lingkungan, sosial) tentunya saling berkaitan dengan sustainability report (SR), dan profit yang ingin dicapai. SR merupakan laporan keberlanjutan yang diterbitkan perusahaan selain laporan keuangan dan tahunan, sebagai bukti pelaksanaan tanggung jawab kepada stakeholders terkait kinerja perusahaan secara berkelanjutan (Supriyadi et al., 2019). Pemenuhan terkait pelaporan keberlanjutan tersebut ditetapkan oleh sebuah lembaga organisasi independen berstandar internasional bernama Global Reporting Initiative (GRI). GRI ini merupakan organisasi atau lembaga yang dijadikan pedoman standarisasi dalam menerapkan sustainability report di Indonesia dan negara tetangga lainnya (Hardiningsih et al., 2020).

Bodhanwala dan Bodhanwala (2018) melakukan penelitian di India sejalan dengan penelitian Zhao et al. (2018) di China, dan penelitian oleh Velte (2017) di Jerman di mana hasil yang ditemukan yaitu pengungkapan CSR berpengaruh signifikan positif terhadap kinerja. Sebaliknya, penelitian di Indonesia oleh Dian (2018), dan Iswati (2020) menemukan pengungkapan CSR di laporan keberlanjutan tidak mempengaruhi kinerja keuangan. Sementara studi Hardiningsih et al. (2020) menyatakan aspek indikator lingkungan dan sosial secara positif signifikan mempengaruhi kinerja keuangan. Bertentangan dengan kedua penelitian oleh Hardi dan Chairina (2019), serta Evana (2017) yang menunjukkan aspek dimensi lingkungan dan sosial tidak mempengaruhi sama sekali, melainkan pengungkapan ekonomi yang secara positif signifikan mempengaruhi kinerja.

Berbanding terbalik dengan studi Erkanawati (2018), di mana pengungkapan ekonomi tidak berkepengaruhan sama sekali, melainkan aspek lingkungan, dan sosial yang mempengaruhi secara positif tidak signifikan. Sedangkan hasil riset Sari dan Andreas (2019), serta Yaparto et al. (2013) menunjukkan tidak memiliki pengaruh sama sekali. Berbeda dengan penemuan Hutagalung dan Harahap (2016) di mana aspek sosial berpengaruh secara signifikan negatif terhadap kinerja keuangan. Penelitian terdahulu yang pernah meneliti mengenai laporan keberlanjutan terhadap kinerja keuangan masih banyak ditemukan hasil yang non-konsisten dan berbeda.

Pemakaian pengukuran GRI oleh Hutagalung dan Harahap (2016), Sejati dan Prastiwi (2015), Adhima (2016), Natalia dan Tarigan (2014), Tarigan dan Semuel (2014), Puspitandari dan Septiani (2017) masih berpedoman pada GRI lama versi tiga yaitu G3. Sementara Dian (2018), Hardi dan Chairina (2019), Evana (2017), Erkanawati (2018), Sari dan Andreas (2019), Iswati (2020), Rosdwianti et al. (2016) juga berpedoman pada GRI lama yaitu versi empat (GRI-G4). Jadi, dapat dilihat bahwa pemakaian pengukuran GRI oleh penelitian-penelitian terdahulu masih banyak yang berpedoman pada GRI lama, seperti versi tiga (G3) dan versi empat (G4). Objek sampel perusahaan yang diteliti juga masih dan hanya terpaku pada satu atau dua sektor saja. 
Jurnal Akuntansi Bisnis, Vol. 19, No. 2, September 2021 ISSN 1412-775X (media cetak) | 2541-5204 (media online)

Penelitian ini bertujuan untuk menguji kembali apakah pengungkapan tanggung jawab sosial dan pertumbuhan pendapatan pada perusahaan berkelanjutan mempengaruhi keberlangsungan kinerja perusahaan (keuangan). Berbeda dengan penelitian terdahulu, penelitian ini berfokus pada pertumbuhan pendapatan dan CSR dengan menggunakan pedoman GRI versi lima paling terbaru, yaitu GRI-Standards tahun 2018 untuk meneliti CSR. Sampel penelitian diambil dari perusahaanperusahaan yang tercatat di BEI periode 2016-2020 yang menerbitkan laporan keberlanjutan, kecuali perusahaan sektor keuangan. Dikecualikan, karena dinilai sensitif pada perubahan akan tingkat suku bunga, dan pengukuran dari rasio keuangan dinilai berbeda dengan perusahaan jenis lain (Widowati et al., 2013). Penelitian ini juga akan menambahkan pengukuran kinerja perusahaan (variabel terikat), seperti return on invested capital (Bodhanwala dan Bodhanwala, 2018), dan economic added value (Abdurachman dan Gustyana, 2019) untuk mengukur kinerja perusahaan. Ditambahkan, karena melihat umumnya penggunaan pengukuran return on asset, dan return on equity oleh penelitian terdahulu, seperti penelitian Rosdwianti et al. (2016), Natalia dan Tarigan (2014), Pan et al. (2014), Hardi dan Chairina (2019), Hardiningsih et al. (2020), Velte (2017), Dian (2018), serta Almira dan Wiagustini (2020).

\section{TINJAUAN LITERATUR DAN PERUMUSAN HIPOTESIS}

\section{Teori Stakeholder}

Donaldson dan Preston (1995) dalam Tarigan dan Semuel (2014) yang merupakan salah seorang pendukung atas teori stakeholder berpendapat bahwa tanggung jawab suatu organisasi kepada para pemangku yang berkepentingan di perusahaan dapat diperluas melalui teori ini. Konsep stakeholder theory, dimaksudkan agar perusahaan mengetahui bahwa perusahaan bukan hanya sebagai entitas yang mementingkan operasi perusahaan saja tetapi juga harus memikirkan manfaat untuk pihak berkepentingan lainnya di perusahaan (Supriyadi et al., 2019) seperti pemegang saham, pemerintah, karyawan, pemasok, konsumen, masyarakat, serta pihak lainnya (Hardiningsih et al., 2020). Dengan begitu, suatu perusahaan akan berada di bawah dukungan dan kepercayaan stakeholders, maka hubungan yang baik sangat dibutuhkan antara perusahaan dengan para pihak yang berkepentingan di perusahaan.

\section{Kinerja Perusahaan}

Faktor utama menurut dan dilihat oleh para pemangku kepentingan (stakeholder) dalam pengambilan keputusan adalah kinerja keuangan. Setiap perusahaan tentunya berkeinginan untuk memiliki kinerja yang baik dengan menghasilkan profit (Pan et al., 2014). Kinerja keuangan dinilai penting sebab untuk melihat bahwa suatu perusahaan yang menerapkan konsep dan praktik keberlanjutan mengalami perkembangan dengan menghasilkan profit (Shakil et al., 2019). Membandingkan kinerja keuangan perusahaan dengan tahun sebelumnya inilah yang membuat para stakeholder dapat melihat pencapaian hasil yang diterima atas aktivitas yang dilakukan perusahaan dalam mengimplementasikan praktik keberlanjutan. Kinerja perusahaan yang baik sangat berperan mempengaruhi kemajuan (Sari dan Andreas, 2019), kelancaran, dan potensi dari 
Jurnal Akuntansi Bisnis, Vol. 19, No. 2, September 2021 ISSN 1412-775X (media cetak) | 2541-5204 (media online)

jalannya proses kegiatan bisnis perusahaan (Bodhanwala dan Bodhanwala, 2018). Rasio keuangan digunakan untuk melihat dan mengukur kondisi keuangan pada suatu perusahaan, serta mengukur besarnya kemampuan suatu perusahaan menghasilkan laba atau profit (Adhima, 2016).

\section{Laporan Keberlanjutan}

Perbincangan terkait CSR tentunya saling berkaitan dengan sustainability report (SR). SR sebagai laporan keberlanjutan bukti hasil dilaksanakannya kinerja keberlanjutan (CSR) oleh perusahaan. Penerbitan laporan keberlanjutan perusahaan sangat berkaitan erat dengan kesinambungan sustainable development (Bodhanwala dan Bodhanwala, 2018). Sustainability report harus sesuai dengan pedoman standarisasi GRI, di mana GRI sebagai lembaga pengatur standar pembuatan, dan pengungkapan isi dalam sustainability report di Indonesia (Hardiningsih et al., 2020). Sejak tahun 2007 silam, di Indonesia telah diresmikan UU Nomor 40 Tahun 2007 pemberlakuan semua perusahaan tercatat di BEI untuk bertanggung jawab secara sosial (Syamni et al., 2018).

Selama 10 tahun terakhir, lembaga GRI terus memperbarui, merevisi, dan menyempurnakan standar pedoman GRI hingga versi kelima sekarang. Penelitian ini akan berpedoman pada GRI paling terbaru versi kelima bernama GRI-Standards 2018 dengan total 89 indeks meliputi total aspek indikator kinerja ekonomi, lingkungan, dan sosial. Indeks indikator pada pedoman GRIStandards versi lima ini diperbarui dengan meluncurkan pedoman terpisah untuk kinerja ekonomi dengan nama (GRI-200), lingkungan (GRI-300), dan sosial (GRI-400) (GRI Standards, 2018).

\section{Pengungkapan CSR dan Kinerja Perusahaan}

Pengungkapan dari dilaksanakannya CSR telah menjadi tuntutan yang harus dipertanggungjawabkan guna mendukung pencapaian pembangunan berkelanjutan (Bodhanwala dan Bodhanwala, 2018). Hal ini untuk meminimalkan setiap dampak yang timbul akibat jalannya bisnis perusahaan baik secara sosial maupun ekonomi (Abdurachman dan Gustyana, 2019). Menurut UU No. 40 tahun 2007 tentang Perseroan Terbatas Pasal 74 Ayat 1, menyebutkan bahwa perseroan yang kegiatan usahanya di bidang dan atau berkaitan dengan sumber daya pada alam wajib melaksanakan tanggung jawab akan sosial dan lingkungan (Otoritas Jasa Keuangan, 2016). Di Indonesia, isu keberlanjutan (CSR) telah menjadi tuntutan penting yang wajib diperhatikan oleh setiap perusahaan dan pelaku bisnis. Jadi, tanggung jawab akan sosial ini, diharapkan dapat meminimalkan setiap konsekuensi negatif akibat jalannya kegiatan bisnis perusahaan kepada masyarakat baik secara sosial maupun ekonomi (Abdurachman dan Gustyana, 2019).

Perusahaan yang berpraktik melaksanakan CSR tentunya juga akan memiliki reputasi yang baik di mata masyarakat dan stakeholders (Aggarwal, 2013), yang mana akan mempengaruhi kinerja perusahaan. Setiap perusahaan yang menjalankan suatu bisnis harus memberikan apresiasi dalam bentuk bertanggung jawab kepada masyarakat setempat secara sosial, baik di lingkungan perusahaan maupun di lingkungan yang mengalami dampak akibat jalannya kegiatan bisnis perusahaan. Sejumlah studi seperti Rosdwianti et al. (2016), Hardiningsih et al. (2020), Syamni et al. (2018), Pan et al. (2014) mengemukakan pengungkapan CSR memberikan pengaruh positif 
Jurnal Akuntansi Bisnis, Vol. 19, No. 2, September 2021 ISSN 1412-775X (media cetak) | 2541-5204 (media online)

kepada kinerja pada perusahaan. Sementara studi Abdurachman dan Gustyana (2019) Hartini dan Rahayu (2018) menunjukkan bahwa pengungkapan CSR tidak memiliki pengaruh yang positif terhadap pencapaian kinerja perusahaan.

\section{H1: Pengungkapan CSR berpengaruh signifikan positif terhadap kinerja perusahaan.}

\section{Pertumbuhan Pendapatan dan Kinerja Perusahaan}

Pertumbuhan yang dialami perusahaan dapat dilihat sebagai suatu peningkatan bagi perusahaan. Perusahaan juga dapat menilai sejauh mana keberadaan perusahaan secara menyeluruh maupun di industri yang sama (Niar, 2019). Perusahaan dengan pertumbuhan (growth) yang cukup tinggi, cenderung memakai dana eksternal dengan jumlah besar (Bodhanwala dan Bodhanwala, 2018) untuk membiayai pengeluaran dari perusahaan (Niar, 2019). Pertumbuhan yang meningkat tentunya membuat perusahaan juga mengharapkan peningkatan pada nilai aset (Abughniem et al., 2020), agar investor ingin berinvestasi untuk keuntungan yang diinginkan dapat terwujud (Putri, 2020). Pertumbuhan dikatakan dapat mempengaruhi pencapaian keuntungan bagi perusahaan, karena aset perusahaan yang dimiliki dapat berdampak pada produktivitas yang di mana dapat mempengaruhi keuntungan (Abughniem et al., 2020). Pertumbuhan pada perusahaan juga dapat memberikan pengaruh akan perubahan pada harga saham.

Pada perusahaan berkelanjutan sendiri, pertumbuhan yang terjadi untuk mengukur apakah suatu perusahaan dalam mengungkapkan CSR mengalami pertumbuhan secara baik atau tidak. Sangat penting untuk perusahaan berperilaku sesuai etika seperti warga yang berkorporat baik, yaitu dengan cara perusahaan mengungkapkan, dan melaksanakan setiap kinerja keberlanjutan. Hal tersebut dapat bermanfaat pada kelangsungan hidup perusahaan (sustainable growth) terutama pertumbuhan perusahaan dalam waktu jangka panjang, di mana hal itu juga akan meningkatkan laba perusahaan (Bodhanwala dan Bodhanwala, 2018). Pada penemuan Arifin et al. (2019), Niar (2019), Putri (2020), dan Sari dan Abundanti (2014) menyatakan pertumbuhan pada perusahaan bersignifikan positif mempengaruhi kinerja. Sedangkan Odalo et al. (2016) menemukan hubungan yang bernegatif signifikan terhadap kinerja perusahaan.

\section{$\mathrm{H}_{2}$ : Pertumbuhan pendapatan berpengaruh signifikan positif terhadap kinerja perusahaan.}

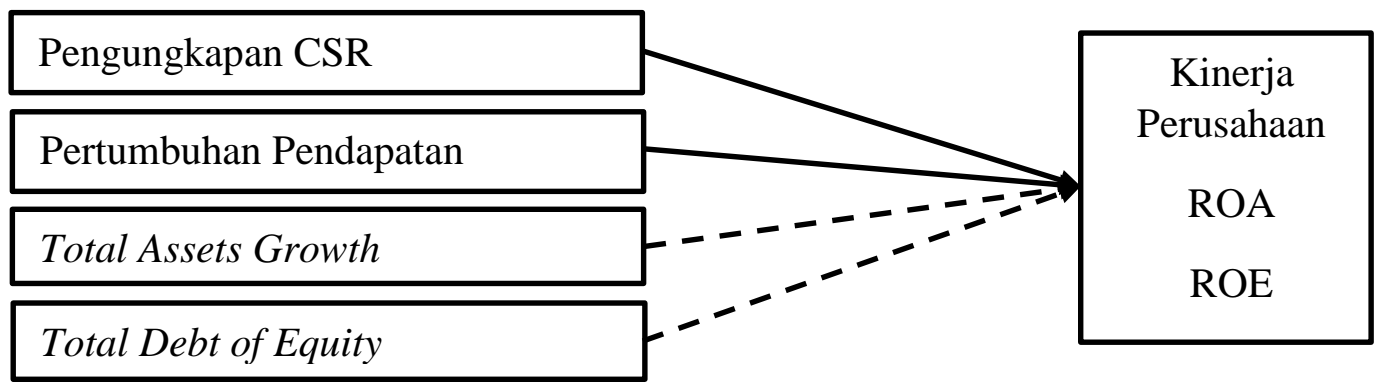

Gambar 1. Model Penelitian 
Jurnal Akuntansi Bisnis, Vol. 19, No. 2, September 2021

ISSN 1412-775X (media cetak) | 2541-5204 (media online)

\section{METODE PENELITIAN}

\section{Populasi dan Sampel}

Sampel objek observasi bersumber dari perusahaan yang berdaftar di BEI periode tahun 2016-2020. Penentuan sampel berdasarkan purposive sampling dengan kriteria: (1) perusahaan non-keuangan tercatat di BEI secara berturut-turut pada periode tahun 2016-2020; (2) perusahaan mempublikasikan dan menyajikan annual report secara lengkap pada periode tahun 2016-2020; serta (3) perusahaan mempublikasikan laporan keberlanjutan berstandar GRI secara lengkap diterbitkan pada periode tahun 2016-2020.

\section{Tabel 1. Prosedur Pemilihan Sampel}

\begin{tabular}{lr}
\hline Keterangan & Total \\
\hline Perusahaan listed di BEI secara berturut-turut periode 2016-2020 & 208 perusahaan \\
Perusahaan di BEI yang tergolong sektor finansial & (18) perusahaan \\
Perusahaan tidak lengkap mempublikasikan annual report periode 2016-2020 & (108) perusahaan \\
Perusahaan tidak lengkap mempublikasikan laporan keberlanjutan periode & (1) perusahaan \\
$2016-2020$ & \\
Perusahaan tidak pernah mempublikasikan laporan keberlanjutan periode & (44) perusahaan \\
2016-2020 & \\
Total sampel memenuhi kriteria & 37 perusahaan \\
Periode tahun penelitian $(2016-2020)$ & 5 tahun \\
Jumlah total data penelitian $(37$ x 5) & 185 data \\
\hline
\end{tabular}

Sumber: Olahan data, 2021

Berlandaskan Tabel 1 terlihat total jumlah perusahaan yang berdaftar dan tercatat di BEI secara berturut-turut selama periode 2016-2020 sebanyak 208 perusahaan. Terdapat juga perusahaan tergolong sektor finansial sejumlah 18 perusahaan dikeluarkan dari daftar sampel. Selanjutnya terdapat 108 perusahaan yang tidak lengkap menerbitkan laporan tahunan dan 1 perusahaan yang tidak lengkap mempublikasikan laporan keberlanjutan pada periode 2016-2020, maka dikeluarkan dari sampel. Sebanyak 44 perusahaan juga dikeluarkan dari sampel karena tidak pernah menerbitkan laporan keberlanjutan sama sekali selama periode 2016-2020. Setelah dilakukan pengurangan, terkumpul sejumlah 37 perusahaan non-keuangan yang mencapai pemenuhan kriteria, yaitu perusahaan menerbitkan laporan tahunan dan laporan keberlanjutan secara lengkap berkesinambungan pada periode 2016-2020. Jadi, total 37 perusahaan non-keuangan ditetapkan sebagai sampel, dengan periode observasi lima tahun (5), maka total jumlah data penelitian berjumlah 185 data.

Tabel 2 merupakan tabel data penelitian terhadap model yang akan digunakan penelitian ini. Terdapat data yang termasuk menyimpang (outlier) pada masing-masing model. Setelah dilakukan pengurangan terhadap data outlier pada keempat model ini, maka total data pengujian yang akan digunakan pada Model I (ROA) yaitu sebanyak 173 data, Model II (ROE) sejumlah 172 
Jurnal Akuntansi Bisnis, Vol. 19, No. 2, September 2021 ISSN 1412-775X (media cetak) | 2541-5204 (media online)

data, Model III (ROIC) sebanyak 173 data, serta Model IV (EVA) 178 data dari 185 total data penelitian.

Tabel 2. Data Penelitian Model

\begin{tabular}{lrrrr}
\hline Keterangan & $\begin{array}{r}\text { Model I } \\
\text { (ROA) }\end{array}$ & $\begin{array}{r}\text { Model II } \\
\text { (ROE) }\end{array}$ & $\begin{array}{r}\text { Model III } \\
\text { (ROIC) }\end{array}$ & $\begin{array}{r}\text { Model IV } \\
\text { (EVA) }\end{array}$ \\
\hline Jumlah total data penelitian & 185 data & 185 data & 185 data & 185 data \\
Jumlah data menyimpang $($ outlier $)$ & $(12)$ data & $(13)$ data & (12) data & (7) data \\
\cline { 2 - 5 } Jumlah total data pengujian & 173 data & 172 data & 173 data & 178 data \\
\hline
\end{tabular}

Sumber: Olahan data, 2021

\section{Definisi dan Pengukuran Variabel Variabel Dependen}

Pada penelitian ini, kinerja perusahaan diproksikan dengan rasio keuangan, guna untuk melihat besarnya tingkat kemampuan kinerja keuangan pada suatu perusahaan dalam menghasilkan laba. Kinerja perusahaan penelitian ini diproksikan dengan:Return of asset (ROA) berguna untuk menilai kinerja dari organisasi, dengan melihat pengelolaan investasi pada pemakaian aset (aktiva) perusahaan dalam penghasilan laba pada perusahaan (Almira \& Wiagustini, 2020). Berikut rumus perhitungan ROA (Natalia \& Tarigan, 2014):

$$
\mathrm{ROA}=\frac{\text { Net Income }}{\text { Total Asset }}
$$

Return of equity (ROE) berguna mengevaluasi seberapa baik efisiensi dari suatu perusahaan memperoleh laba yang bersih dalam penggunaan modal yang dimiliki (Almira \& Wiagustini, 2020). Berikut rumus ROE (Natalia \& Tarigan, 2014):

$$
\begin{aligned}
& \mathrm{ROE}= \text { Net Income } \\
& \text { Total Equity }
\end{aligned}
$$

Return on invested capital (ROIC) ini untuk menghitung seberapa baik perusahaan mengembalikan jumlah penggunaan modal yang dipakai dengan menghasilkan laba yang lebih besar dari pengeluaran modal investasi perusahaan. Rasio ini didapat dengan cara melihat laba bersih dari suatu perusahaan terhadap total hutang dan total ekuitas. Berikut rumus perhitungan ROIC (Bodhanwala \& Bodhanwala, 2018):

ROIC $=\frac{\text { Laba Bersih }}{\text { Total Hutang }+ \text { Total Ekuitas }}$

Economic value added (EVA) berguna mengukur tingkat nilai yang bertambah dari hasil penghasilan perusahaan dengan melihat besarnya biaya (modal) dari investasi (Nugrahanti \& Maharani, 2013). Perusahaan mengalami peningkatan nilai ekonomis jika nilai EVA $>0$. Sementara jika EVA bernilai <0, maka perusahaan tidak mengalami pertambahan nilai ekonomis. Selanjutnya jika nilai $\mathrm{EVA}=0$, maka terjadi keadaan impas di mana pembayaran telah dilakukan terhadap kewajiban kepada kreditor, penyandang dana maupun stakeholders melalui penghasilan laba 
Jurnal Akuntansi Bisnis, Vol. 19, No. 2, September 2021 ISSN 1412-775X (media cetak) | 2541-5204 (media online)

(Nugrahanti \& Maharani, 2013). Berikut rumus perhitungan EVA (Abdurachman \& Gustyana, 2019):

EVA $=$ NOPAT - Capital Charge

\section{Variabel Independen}

Tanggung jawab secara sosial merupakan komitmen usaha untuk bertindak secara etis, beroperasi secara legal, dan berkontribusi mengembangkan keberlanjutan ekonomi bersamaan peningkatan kualitas hidup dari anggota perusahaanxdan masyarakat secara lebih luas (Shakil et al., 2019). Disesuaikan dengan pedoman dari GRI-Standards, total keseluruhan indeks pengungkapan CSR berjumlah 89 (GRI Standards, 2018) yang akan diasumsikan sebagai. Perhitungan pengungkapan CSR diproksikan dengan CSRDI (Corporate Social Responsibility Disclosure Index), di mana total disclosure pengungkapan yang diungkapkan diasumsikan sebagai. Setiap item indikator keberlanjutan yang diungkapkan akan bernilai satu (1), dan sebaliknya penilaian nol (0) diberikan, jikalau pada laporan keberlanjutan terdapat tidak diungkapkannya item indikator keberlanjutan (Rosdwianti et al., 2016). Berikut dilampirkan rumus perhitungan CSRDI:

$\operatorname{CSRDI}=\frac{\mathrm{X}}{\mathrm{N}}$

Pertumbuhan pendapatan (REVGROWTH) untuk mengukur apakah suatu perusahaan berkelanjutan yang menyajikan laporan keberlanjutan mengalami peningkatan pendapatan pada setiap periode tahun berjalan dengan melihat dari sisi kinerja. Pertumbuhan pendapatan perusahaan diukur dengan membandingkan pendapatan pada tahun sebelumnya dan tahun sekarang. Berikut dilampirkan rumus perhitungan REVGROWTH (Bodhanwala dan Bodhanwala, 2018):

$$
\text { REVGROWTH }=\frac{\text { Revenue }_{\mathrm{t}}-\text { Revenue }_{\mathrm{t}-1}}{\text { Revenue }_{\mathrm{t}-1}}
$$

\section{Variabel Kontrol}

Total Asset Growth (TAGROWTH) untuk mengetahui mengenai pertumbuhan total aset pada suatu perusahaan, dengan cara melihat perubahan total aset yang terjadi pada tahun sebelumnya dan dibandingkan dengan tahun sekarang, apakah mengalami pertumbuhan atau tidak. Berikut dilampirkan rumus perhitungan TAGROWTH (Bodhanwala dan Bodhanwala, 2018), yakni:

$$
\text { TAGROWTH }=\frac{\text { Total Aset } \mathrm{t}_{\mathrm{t}}-\text { Total Aset }_{\mathrm{t}-1}}{\text { Total }_{\text {Aset }}-1}
$$

Debt to Equity Ratio (DER) diukur melihat total dari sebuah hutang (jangka panjang dan jangka pendek) pada perusahaan terhadap modal (ekuitas). Rasio DER termasuk bagian dari rasio leverage $(L E V)$, berguna menilai betapa baiknya struktur investasi pada posisi keuangan perusahaan. Berikut dilampirkan rumus perhitungan DER (Bodhanwala dan Bodhanwala, 2018):

$$
\text { DER }=\frac{\text { Total Hutang }}{\text { Total Ekuitas }}
$$


Jurnal Akuntansi Bisnis, Vol. 19, No. 2, September 2021 ISSN 1412-775X (media cetak) | 2541-5204 (media online)

\section{Teknik Pengumpulan Data dan Analisis}

Penelitian ini merupakan penelitian bersifat kuantitatif dengan data berjenis sekunder (Kurniawan dan Puspitaningtyas, 2016), yaitu keperluan data penelitian didapat dari dokumen berupa annual report yang ditelusuri dari BEI, dan laporan keberlanjutan dari situs resmi website perusahaan. Penekanan pada penelitian ini, yaitu menguji teori-teori dengan mengukur setiap variabel pada penelitian ini dalam ukuran skala bentuk angka (numerik). Selain itu, penelitian juga akan melaksanakan analisis terhadap data-data penelitian secara deskriptif. Data berjenis sekunder dari sampel penelitian didapatkan dari hasil pemilihan perusahaan di BEI. Langkah proses pengujian penelitian, yaitu uji statistik deskriptif, uji outlier, uji pemilihan model terbaik (uji chow, hausman, lagrange multiplier), serta pengujian hipotesis. Metode analisis mempergunakan regresi data berbasis panel dengan program Eviews $v 11$, guna mencari tahu hubungan keterkaitan antar variabel independen terhadap variabel dependen. Berikut persamaan regresi model yang digunakan, yaitu:

1. $\mathrm{ROA}=\alpha+\beta_{1} * \mathrm{CSRDI}+\beta_{2} * R E V G R O W T H+\beta_{3} *$ TAGROWTH $+\beta_{4} * \mathrm{DER}+\varepsilon$

2. $\mathrm{ROIC}=\alpha+\beta_{1} * \mathrm{CSRDI}+\beta_{2} *$ REVGROWTH $+\beta_{3} * T A G R O W T H+\beta_{4} * \mathrm{DER}+\varepsilon$

3. $\mathrm{ROE}=\alpha+\beta_{1} * \mathrm{CSRDI}+\beta_{2} * R E V G R O W T H+\beta_{3} * T A G R O W T H+\beta_{4} * \mathrm{DER}+\varepsilon$

4. $\mathrm{EVA}=\alpha+\beta_{1} * \mathrm{CSRDI}+\beta_{2} * R E V G R O W T H+\beta_{3} * T A G R O W T H+\beta_{4} * \mathrm{DER}+\varepsilon$

\section{HASIL DAN PEMBAHASAN}

\section{Statistik Deskriptif}

Gambaran Tabel 3 secara numerik ialah hasil pelaksanaan pengujian dari statistika secara deskriptif. Pengujian ini memperlihatkan uraian data-data dari data bernilai terkecil, paling besar, hingga nilai rata-rata dari keseluruhan total data penelitian, serta standar deviasi atas data pada setiap variabel penelitian.

Tabel 3. Statistik Deskriptif

\begin{tabular}{lcrrrr}
\hline & N & Minimum & Makimum & Rata-Rata & Std. Deviasi \\
\hline ROA & 185 & -0.6312 & 0.5267 & 0.0500 & 0.1135 \\
ROE & 185 & -4.1125 & 1.5360 & 0.1080 & 0.4772 \\
ROIC & 185 & -0.6312 & 0.5267 & 0.0497 & 0.1152 \\
EVA & 185 & -32668667456260 & 10856212736447 & 737149008439 & 3105741124672 \\
CSRDI & 185 & 0.0000 & 0.8876 & 0.3306 & 0.1791 \\
REVGROWTH & 185 & -0.9163 & 67.4292 & 0.4247 & 4.9627 \\
TAGROWTH & 185 & -0.3462 & 2.1701 & 0.0968 & 0.2442 \\
DER & 185 & -3.4336 & 24.8489 & 1.6747 & 2.3468 \\
\hline
\end{tabular}

Sumber: Olahan data, 2021

Rata-rata kemampuan perusahaan berkelanjutan di BEI dapat menghasilkan laba hanya sebesar $05.00 \%$ dari total aset. Sementara rata-rata perusahaan berkelanjutan berkemampuan menghasilkan profit sebesar $10.80 \%$ dari penggunaan modal (ekuitas) yang dimiliki. Pengembalian 
Jurnal Akuntansi Bisnis, Vol. 19, No. 2, September 2021 ISSN 1412-775X (media cetak) | 2541-5204 (media online)

penginvestasian modal yang bisa dikembalikan oleh rata-rata perusahaan berkelanjutan hanya berkisar $4.97 \%$ dari penggunaan modal. Walau begitu, nilai ekonomis rata-rata perusahaan masih mengalami perkembangan (EVA>0). Pengungkapan CSR sendiri juga hanya diungkapkan oleh rata-rata perusahaan sebesar $33.06 \%$ dari 89 item. Bagi perusahaan yang mengungkapkan CSR tentunya merasakan peningkatan pada total aset dan pertumbuhan pada pendapatan. Rendahnya pengungkapan terlihat dari laporan keberlanjutan yang menunjukkan kurang maksimalnya setiap perusahaan melaksanakan CSR. Maka dari itu, terdapat perusahaan berkelanjutan yang menjumpai kerugian. Hal ini terlihat dari nilai ROA, ROE, ROIC, EVA yang negatif.

Tabel 4. Hasil Uji Pemilihan Model Estimasi

\begin{tabular}{cccccccc}
\hline \multirow{2}{*}{ Model } & \multicolumn{2}{c}{ Chow Test } & \multicolumn{2}{c}{ Hausman Test } & \multicolumn{2}{c}{ LM Test } & \multirow{2}{*}{ Kesimpulan } \\
& Chi-Square & Prob. & Chi-Square & Prob. & Breusch-Pagan & Prob. & \\
\hline ROA & 169.9569 & 0.0000 & 5.8055 & 0.2142 & 92.0506 & 0.0000 & Random Effects Model \\
ROE & 113.3856 & 0.0000 & 30.9376 & 0.0000 & - & - & Fixed Effects Model \\
ROIC & 170.1331 & 0.0000 & 5.8187 & 0.2131 & 92.1690 & 0.0000 & Random Effects Model \\
EVA & 190.9403 & 0.0000 & 11.6682 & 0.0200 & - & - & Fixed Effects Model \\
\hline
\end{tabular}

Sumber: Olahan data, 2021

Tampilan Tabel 4 menampakkan hasil dari pengujian pemilihan model. Terdapat tiga tahap pengujian, yaitu uji Chow, uji Hausman, dan uji Lagrange Multiplier (LM). (1) Pengujian Chow merupakan langkah pertama untuk memilih model estimasi untuk pengujian antara model pooled least square (PLS) atau fixed effect model (FEM). Jika hasil prob. uji Chow < 0.05, maka FEM terpilih, tapi jika sebaliknya maka model PLS terpilih; (2) tahap pengujian kedua yaitu Hausman, guna untuk menentukan model estimasi antara model FEM atau random effect model (REM). Jika hasil prob. uji Hausman < 0.05, maka FEM terpilih, tapi jika sebaliknya maka REM terpilih; (3) langkah pengujian ketiga yaitu uji LM untuk menentukan antara REM atau model PLS. Pengujian LM adalah pengujian akhir yang dilakukan akibat hasil yang bertolak belakang antara tahap (1) dan (2). Jika hasil prob. uji LM < 0.05, maka REM terpilih, tapi jika sebaliknya maka PLS terpilih. Hasil uji Chow pada empat model secara serupa sebesar $0.0000(<0.05)$, sehingga FEM terpilih. Selanjutnya dilanjutkan uji Hausman, menunjukkan hasil prob. dua model (ROA dan ROIC) $>0.05$, sehingga akan dilanjutkan ke pengujian LM. Model ROE dan EVA dikecualikan dari uji LM, sebab hasil prob. uji Chow dan Hausman sama-sama <0.05, maka FEM terpilih untuk digunakan. Sementara model ROA dan ROIC akan menggunakan REM sebagai model terbaik. Hal ini ditampakkan dari hasil uji Hausman menunjukkan hasil prob.>0.05, serta hasil prob. uji $\mathrm{LM}<0.05$.

\section{Pengujian Hipotesis}

Melaksanakan pengujian F (simultan) ini, bertujuan menimbulkan pemahaman mengenai apakah variabel terikat (dependen) secara simultan terpengaruhi oleh variabel bebas (independen). Tabel 5 memperlihatkan bahwa hasil pengujian probabilitas $\mathrm{F}$ statistik di bawah atau lebih kecil dari 0.05 (0.0000<0.05). Maka, variabel pengungkapan tanggung jawab sosial (CSR) dan variabel 
Jurnal Akuntansi Bisnis, Vol. 19, No. 2, September 2021 ISSN 1412-775X (media cetak) | 2541-5204 (media online)

pertumbuhan pendapatan secara simultan berhasil memberikan pengaruh signifikan kepada kinerja perusahaan yang diukur dengan ROA, ROE, ROIC, dan EVA.

Tabel 5. Hasil Pengujian F

\begin{tabular}{ccc}
\hline Variabel Dependen (Kinerja) & Prob(F-statistic) & Kesimpulan \\
\hline Model I (ROA) & 0.0000 & Signifikan \\
Model II (ROE) & 0.0000 & Signifikan \\
Model III (ROIC) & 0.0000 & Signifikan \\
Model IV (EVA) & 0.0000 & Signifikan \\
\hline
\end{tabular}

Sumber: Olahan data, 2021

Menjalankan pengujian secara t (parsial) ini, bertujuan mendapatkan pemahaman terkait seberapa pengaruhnya setiap variabel-variabel yang bebas (independen) secara individual meneruskan akibat kepada variabel terikat (dependen). Pemahaman secara parsial ini, terkait tiap individual variabel bebas dapat dilakukan pengamatan melalui model terpilih dari pengujian regresi data panel.

Tabel 6. Hasil Pengujian t Model I (ROA)

\begin{tabular}{cccll}
\hline Variabel & Koefisien & Sig. & Kesimpulan & Hipotesis \\
\hline CSRDI & 0.0159 & 0.4131 & Tidak Signifikan & Tidak Terbukti \\
REVGROWTH & 0.0003 & 0.5196 & Tidak Signifikan & Tidak Terbukti \\
TAGROWTH & 0.0869 & 0.0000 & Signifikan Positif & \\
DER & -0.0068 & 0.0000 & Signifikan Negatif & \\
\hline
\end{tabular}

Sumber: Olahan data, 2021

Hasil signifikansi CSRDI di Tabel 6 menunjukan penolakan pada hipotesis 1 (0.4131>0.05), artinya pengungkapan CSR di laporan keberlanjutan tidak berkemampuan mempengaruhi kinerja perusahaan proksi ROA. Maka terjadi penolakan pada hipotesis 1. Lain hal dengan ketiga riset oleh Puspitandari dan Septiani (2017), dan Retnosari (2018) yang menemukan kepengaruhan positif yang signifikan kinerja (ROA). Akan tetapi, hasil ini serupa dengan penelitian Sari dan Andreas (2019), Sejati dan Prastiwi (2015), Hutagalung dan Harahap (2019) dengan asumsi bahwa pengungkapan CSR tidak akan mempengaruhi kinerja dalam waktu jangka pendek melainkan secara jangka hanjang. Hal ini dikarenakan, biaya pelaksanaan CSR yang dikeluarkan perusahaan saat ini sebagai strategi investasi jangka panjang, yang nantinya akan kembali sebagai profit perusahaan pada beberapa tahun ke depan. Hal ini ditunjukkan dengan hasil signifikansi TAGROWTH $\quad(0.000<0.05)$ artinya perusahaan yang mengungkapkan CSR mengalami peningkatan pada aset yang dimilikinya, sehingga di masa depan nanti akan memberikan keuntungan bagi perusahaan.

Pada Tabel 6 juga terlihat bahwa variabel signifikansi REVGROWTH berada di atas 0.05 (0.5196), artinya pertumbuhan pendapatan pada perusahaan berkelanjutan tidak berkemampuan mempengaruhi kinerja perusahaan (ROA). Maka terjadi penolakan pada hipotesis 2. Bertolak dengan penelitian oleh Bodhanwala dan Bodhanwala (2018), Sari dan Abundanti (2014), serta Putri (2020) yang menemukan kepengaruhan positif antara pertumbuhan pendapatan perusahaan 
Jurnal Akuntansi Bisnis, Vol. 19, No. 2, September 2021 ISSN 1412-775X (media cetak) | 2541-5204 (media online)

terhadap kinerja. Hasil ini sesuai dengan penelitian Putra dan Badjra (2015) dengan asumsi terjadinya pertumbuhan pendapatan pada perusahaan berkelanjutan bersamaan dengan terus terjadinya penambahan aset dan pengeluaran biaya yang juga besar, maka pencapaian kinerja yang diinginkan pun tidak akan terwujud. Maka dari itu, pertumbuhan pendapatan tidak berkemampuan mempengaruhi kinerja perusahaan.

Tabel 7. Hasil Pengujian t Model II (ROE)

\begin{tabular}{ccccc}
\hline Variabel & Koefisien & Sig. & Kesimpulan & Hipotesis \\
\hline CSRDI & 0.0972 & 0.1609 & Tidak Signifikan & Tidak Terbukti \\
REVGROWTH & 0.0151 & 0.0000 & Signifikan Positif & Terbukti \\
TAGROWTH & 0.2376 & 0.0000 & Signifikan Positif & \\
DER & -0.0990 & 0.0000 & Signifikan Negatif & \\
\hline
\end{tabular}

Sumber: Olahan data, 2021

Tabel 7 memperlihatkan nilai signifikansi CSRDI terhadap ROE sebesar 0.1609 (>0.05), artinya pengungkapan CSR di laporan keberlanjutan tidak memiliki kepengaruhan terhadap kinerja (ROE). Jadi hipotesis 1 tidak terbukti. Berbanding terbalik dengan studi oleh Bodhanwala dan Bodhanwala (2018), dan Retnosari (2018) yang menemukan pengaruh secara positif signifikan terhadap ROE. Hasil ini sejalan dengan ketiga studi oleh Dian (2018), Hartini dan Rahayu (2018), Hutagalung dan Harahap (2019), serta Yaparto et al. (2013), di mana perusahaan yang secara kompetitif melaksanakan CSR, sering kali mengeluarkan biaya secara besar. Pengeluaran biaya yang tidak diperlukan secara besar dapat berperan membatasi pencapaian keuntungan perusahaan dan akibatnya tidak mempengaruhi kinerja perusahaan sama sekali. Hal ini mengakibatkan, investor meragukan kualitas dari pengungkapan CSR di laporan keberlanjutan dikarenakan tidak adanya pengaruh terhadap kinerja organisasi (Yaparto et al., 2013).

Hasil signifikansi REVGROWTH menunjukan hipotesis 2 diterima $(0.0000<0.05)$, berarti pertumbuhan pendapatan yang dialami perusahaan berkelanjutan positif mempengaruhi kinerja pada perusahaan yang diukur dengan ROE. Hasil ini tidak sejalan dengan penelitian oleh Putra dan Badjra (2015) yang menemukan tidak adanya hubungan antara pertumbuhan pendapatan dan kinerja. Namun, hasil ini searah dengan Arifin et al. (2019), Putri (2020), Sari dan Abundanti (2014), serta Niar (2019) dengan beranggapan bahwa pertumbuhan pendapatan pada perusahaan berkelanjutan yang melaksanakan CSR dan disertai dengan terjadinya peningkatan pada aset yang dimiliki oleh perusahaan mampu berdampak positif terhadap jalannya kegiatan produktivitas perusahaan. Hal ini, tentunya akan mengarah kepada penghasilan laba perusahaan. Jadi, dapat dikatakan bahwa terjadinya pertumbuhan pendapatan mampu mempengaruhi kinerja suatu perusahaan.

Tabel 8. Hasil Pengujian t Model III (ROIC)

\begin{tabular}{ccccl}
\hline Variabel & Koefisien & Sig. & Kesimpulan & Hipotesis \\
\hline CSRDI & 0.0159 & 0.4116 & Tidak Signifikan & Tidak Terbukti \\
REVGROWTH & 0.0003 & 0.5199 & Tidak Signifikan & Tidak Terbukti \\
TAGROWTH & 0.0869 & 0.0000 & Signifikan Positif & \\
DER & -0.0068 & 0.0000 & Signifikan Negatif & \\
\hline
\end{tabular}

Sumber: Olahan data, 2021 
Jurnal Akuntansi Bisnis, Vol. 19, No. 2, September 2021 ISSN 1412-775X (media cetak) | 2541-5204 (media online)

Tabel 8 di atas menunjukkan nilai sig. pengungkapan CSRDI yang berada di atas melebihi 0.05 (0.4116). Hal ini dinyatakan bahwa, pengungkapan CSR di laporan keberlanjutan tidak mempengaruhi kinerja perusahaan yang diproksi dengan ROIC. Jadi hipotesis 1 tidak terbukti. Hasil ini tidak sejalan dengan Bodhanwala dan Bodhanwala (2018), dan Lestari dan Lelyta (2019) yang menemukan kepengaruhan positif signifikan terhadap ROIC. Jadi dapat dikatakan bahwa pengungkapan CSR yang dilakukan perusahaan masih banyak yang hanya sebatas pemenuhan kewajiban saja. Hal ini dpaat dikatakan bahwa perusahaan kurang pintar dalam menjadikan pengungkapan CSR sebagai strategi bisnis. Maka dari itu, pengungkapan CSR yang diungkapkan oleh perusahaan tidak berkemampuan mempengaruhi kinerja. Hal inilah yang menurunkan ketertarikan investor untuk berinvestasi kepada perusahaan, karena melihat tidak adanya keterkaitan ataupun pengaruh pengungkapan CSR terhadap kinerja organisasi (Sari \& Abundanti, 2014).

Hasil signifikansi REVGROWTH menunjukan hipotesis 2 mengalami penolakan $(0.5199<0.05)$, berarti pertumbuhan pendapatan yang dialami perusahaan berkelanjutan tidak berpengaruh pada kinerja perusahaan (ROIC). Hasil ini tidak searah dengan Bodhanwala dan Bodhanwala (2018), Arifin et al. (2019), serta Sari dan Abundanti (2014) yang mengemukakan signifikan positif mempengaruhi kinerja perusahaan. Hal ini dapat diartikan bahwa perusahaan yang mengalami pertumbuhan pendapatan bukan berarti dapat mempengaruhi kinerja suatu organisasi (Abughniem et al., 2020). Pengeluaran biaya operasional berskala besar terutama dalam hal penambahan aset membuat pertumbuhan pendapatan suatu organisasi tidak berdampak pada kinerja. Jadi, dapat dinyatakan bahwa pertumbuhan pendapatan yang terjadi tidak berdampak mempengaruhi kinerja perusahaan (Abughniem et al., 2020), sehingga mengakibatkan tidak terwujudnya keuntungan yang investor inginkan (rate of return).

Tabel 9. Hasil Pengujian t Model IV (EVA)

\begin{tabular}{crrlc}
\hline Variabel & Koefisien & Sig. & Kesimpulan & Hipotesis \\
\hline CSRDI & $1.21 \mathrm{E}+12$ & 0.0186 & Signifikan Positif & Terbukti \\
REVGROWTH & $-1.70 \mathrm{E}+10$ & 0.2791 & Tidak Signifikan & Tidak Terbukti \\
TAGROWTH & $1.03 \mathrm{E}+12$ & 0.0006 & Signifikan Positif & \\
DER & $-4.50 \mathrm{E}+10$ & 0.5834 & Tidak Signifikan & \\
\hline
\end{tabular}

Sumber: Olahan data, 2021

Berdasarkan hasil pengujian t Tabel 9 dapat dilihat bahwa nilai signifikansi pengungkapan CSR berada di bawah angka 0.05 (0.0186). Hal ini berarti, pengungkapan CSR di laporan keberlanjutan berpengaruh secara positif bersignifikan terhadap kinerja yang diproksi dengan EVA. Jadi hipotesis 1 diterima. Berbeda dengan penelitian Dian (2018) dan Iswati (2020) yang menemukan tidak adanya kepengaruhan antara pengungkapan CSR dan kinerja keuangan. Hasil ini setara dengan Hartini dan Rahayu (2018) serta Nugrahanti dan Maharani (2013), yaitu pengungkapan CSR oleh perusahaan berkelanjutan berhasil mendapatkan keyakinan para konsumen, sebab loyalitas konsumen didapat dari transparannya informasi pengungkapan CSR oleh perusahaan. Terlaksananya pengungkapan CSR juga mampu memberikan nilai tambah pada 
Jurnal Akuntansi Bisnis, Vol. 19, No. 2, September 2021 ISSN 1412-775X (media cetak) | 2541-5204 (media online)

perusahaan, sehingga calon investor tertarik berinvestasi pada perusahaan yang secara serius melaksanakan setiap pengungkapan CSR. Hal ini berarti, pengungkapan CSR di laporan keberlanjutan mampu secara positif mempengaruhi kinerja organisasi. Peningkatan pada nilai aset yang dimiliki perusahaan juga membuktikan bahwa harapan investor atas keuntungan yang diinginkan itu terwujud (Abughniem et al., 2020).

Hasil signifikansi REVGROWTH sendiri menunjukan bahwa hipotesis 2 mengalami penolakan $(0.2791<0.05)$, berarti pertumbuhan pendapatan yang dialami perusahaan berkelanjutan tidak berkemampuan mempengaruhi kinerja suatu organisasi (EVA). Hal ini diakibatkan terjadinya penambahan aset memicu tingginya pengeluaran biaya operasional, maka menutup kesempatan terwujudnya pencapaian keuntungan yang diinginkan (Putra \& Badjra, 2015). Hasil ini sesuai dengan Saputri dan Giovanni (2014), dengan anggapan bahwa pertumbuhan pendapatan yang meningkat tidak akan memiliki pengaruh terhadap kinerja dan nilai perusahaan. Hal tersebut dikarenakan, pertumbuhan yang tinggi membuat perusahaan membutuhkan dana yang juga tinggi demi kelancaran kegiatan bisnis operasional perusahaan. Maka dari itu, pertumbuhan pendapatan yang dialami perusahaan tidak berkemampuan mempengaruhi kinerja suatu organisasi. Hal ini tentunya juga dapat menggoyahkan kesejahteraan dari pemegang saham.

Tabel 10. Hasil Pengujian $\mathbf{R}^{2}$

\begin{tabular}{ccc}
\hline Variabel Dependen (Kinerja) & Adjusted R-squared & Persentase \\
\hline Model I (ROA) & 0.2427 & $24.27 \%$ \\
Model II (ROE) & 0.8119 & $81.19 \%$ \\
Model III (ROIC) & 0.2430 & $24.30 \%$ \\
Model IV (EVA) & 0.5999 & $59.99 \%$ \\
\hline
\end{tabular}

Sumber: Olahan data, 2021

Hasil Adjusted $R^{2}$ pada Tabel 10 menunjukkan bahwa variabel CSR, dan pertumbuhan pendapatan hanya bisa menjelaskan variabel dependen (kinerja) Model I (ROA) sebesar 24.27\%, dan Model III (ROIC) senilai 24.30\%. Sedangkan sisanya sebesar $75.73 \%$ dan $75.70 \%$ diberikan penerangan dan dijelaskan oleh variabel bebas (independen) lain yang terletak di luar dan selain terdapat pada model. Namun, variabel CSR, dan pertumbuhan pendapatan mampu menjelaskan Model II (ROE) dan Model IV (EVA) dengan cukup baik di mana pada Tabel 10 hasil persentase Model II (ROE) sebesar 81.19\% dan Model IV (EVA) sebesar 59.99\%. Sedangkan sisanya sebesar $18.81 \%$ dan $40.01 \%$ diberikan penerangan dan dipaparkan oleh variabel bebas (independen) lain yang terletak di luar dan selain terdapat pada model.

\section{SIMPULAN}

Hasil kesimpulan setelah dilaksanakannya pengujian hipotesis (uji parsial), maka dapat disimpulkan bahwa $\mathrm{H}_{1}$ terkait pengungkapan CSR terdapat pengaruh yang signifikan positif pada kinerja perusahaan (EVA). Pengungkapan CSR yang baik oleh perusahaan berkelanjutan dapat memperoleh keyakinan para konsumen dan investor. Terlaksananya pengungkapan CSR yang baik juga mampu memberikan nilai tambah pada perusahaan. Sedangkan pengungkapan CSR tidak 
Jurnal Akuntansi Bisnis, Vol. 19, No. 2, September 2021 ISSN 1412-775X (media cetak) | 2541-5204 (media online)

terdapat pengaruh terhadap kinerja perusahaan yang diukur dengan ROA, ROE, dan ROIC. Hal ini karena pengaruh pengungkapan CSR di laporan keberlanjutan terhadap kinerja tidak dapat dirasakan dalam waktu singkat, melainkan dalam jangka waktu yang panjang. Hal tersebut dapat terjadi, sebab penerapan bisnis yang berkelanjutan sama dengan perusahaan berinvestasi secara jangka panjang demi kelangsungan bisnis dan reputasi perusahaan kedepannya.

Selanjutnya $\mathrm{H}_{2}$ terkait pertumbuhan pendapatan pada perusahaan berkelanjutan mampu mempengaruhi secara signifikan positif terhadap kinerja perusahaan (ROE). Keberhasilan pertumbuhan pendapatan dalam menutupi pengeluaran biaya operasional di bawahnya dengan masih memiliki pendapatan bersih yang tinggi, menunjukkan bahwa pertumbuhan pendapatan tersebut berhasil mempengaruhi kinerja perusahaan dalam menghasilkan keuntungan. Sementara, pertumbuhan pendapatan pada perusahaan berkelanjutan tidak terdapat pengaruh terhadap kinerja yang diproksikan dengan ROA, ROIC, dan EVA. Pengeluaran biaya yang jauh lebih tinggi dibandingkan peningkatan pendapatan yang dialami perusahaan membuat pertumbuhan pendapatan tersebut tidak berkemampuan mempengaruhi kinerja. Hal ini sering kali menggoyahkan kesejahteraan dari pemegang saham dan berdampak pada pengambilan keputusan stakeholders.

Temuan penelitian ini memperlihatkan pertumbuhan pendapatan dan pengungkapan CSR di laporan keberlanjutan signifikan terhadap kinerja perusahaan. Ini menunjukkan sangat penting untuk perusahaan terus mengungkapkan CSR secara lebih dalam lagi sebagai bukti bahwa kepedulian perusahaan akan praktik bisnis yang berkelanjutan. Perusahaan juga jangan hanya sekedar melakukan pengungkapan saja agar terlihat baik tetapi perusahaan harus pintar dalam melancarkan strategi keberlanjutan tersebut dalam pelaksanaan bisnis agar mempengaruhi kinerja perusahaan. Implementasi strategi keberlanjutan (CSR) secara lebih luas mampu membawa perusahaan berkelanjutan mengalami pertumbuhan pendapatan yang akan mengarah ke kinerja perusahaan. Apalagi banyak investor saat ini mementingkan peningkatan investasi dengan penerapan bisnis keberlanjutan yang baik. Investor sendiri juga harus selektif saat berinvestasi pada perusahaan berkelanjutan. Investor juga harus menganggap faktor keberlanjutan sepenting faktor keuangan sebagai pertimbangan. Saran untuk penelitian serupa selanjutnya, yaitu: (1) diharapkan dapat melakukan pengembangan terhadap variabel keberlanjutan lainnya yang dapat berdampak memberikan pengaruh kepada kinerja perusahaan; (2) diharapkan penelitian laporan keberlanjutan selanjutnya terus ber-guidelines pada GRI-Standards 2018; (3) diharapkan penelitian selanjutnya dapat memperluas sampel perusahaan berkelanjutan selain di BEI.

\section{DAFTAR PUSTAKA}

Abdurachman, A., \& Gustyana, T. T. (2019). Analisis pengaruh corporate social responsibility (csr) terhadap economic value added (eva) dan market value added (mva). JIM UPB (Jurnal Ilmiah Manajemen Universitas Putera Batam), 7(1), 107. https://doi.org/10.33884/jimupb.v7i1.948

Abughniem, M. S., Al Aishat, M. A. H., Hamdan, A., \& Weshah, S. R. (2020). Capital structure, firm growth and firm performance: evidence from jordan. International Journal of Innovation, 
Jurnal Akuntansi Bisnis, Vol. 19, No. 2, September 2021 ISSN 1412-775X (media cetak) | 2541-5204 (media online)

Creativity and Change, 10(12), 655-667.

Adhima, M. F. (2016). Pengaruh pengungkapan sustainability report terhadap profitabilitas perusahaan studi kasus pada perusahaan manufaktur yang terdaftar dalam bursa efek indonesia. Jurnal Ilmiah Mahasiswa FEB, 1(1). http://library1 .nida.ac.th/termpaper6/sd/2554/19755.pdf

Aggarwal, P. (2013). Impact of sustainability performance of company on its financial performance: a study of listed indian companies. Global Journal of Management and Business Research Finance Volume, 13(11). www.researchgate.net/publication/323456998\%0AImpact

Almira, N. P. A. K., \& Wiagustini, N. L. P. (2020). Return on asset, return on equity, dan earning per share berpengaruh terhadap return saham. E-Jurnal Manajemen Universitas Udayana, 9(3), 1069. https://doi.org/10.24843/ejmunud.2020.v09.i03.p13

Amanda, G. (2021, February 25). Kinerja keuangan asii alami penurunan selama 2020. Www.Republika.Co.Id. https://www.republika.co.id/berita/qp35yi423/kinerja-keuangan-asiialami-penurunan-selama-2020

Arifin, D. S., Sarita, B., Montundu, Y., \& Madi, R. A. (2019). Pengaruh likuiditas, leverage, ukuran perusahaan dan pertumbuhan penjualan terhadap profitabilitas (studi pada perusahaan property dan real estate yang terdaftar di bursa efek indonesia tahun 2013-2017). Jurnal Manajemen Dan Kewirausahaan, 11(2), 38-52.

Bodhanwala, S., \& Bodhanwala, R. (2018). Does corporate sustainability impact firm profitability? Evidence from India. Management Decision, 56(8), 1734-1747. https://doi.org/10.1108/MD-04-2017-0381

Centre For Risk Management \& Sustainability Indonesia. (n.d.). Mencermati tren keberlangsungan perusahaan di indonesia. Www.Crmsindonesia.Org. Retrieved October 9, 2020, from https://crmsindonesia.org/publications/mencermati-tren-keberlangsungan-perusahaan-diindonesia/

Dian, A. S. (2018). The effect of sustainability report disclosure on financial performance. Russian Journal of Agricultural and Socio-Economic Sciences, 81(9), 1050-1055. https://doi.org/10.5220/0009502610501055

Donaldson, T., \& Preston, L. E. (1995). The stakeholder theory of the corporation: concepts, evidence, and implications. The Academy of Management Review, 20(1), 65. https://doi.org/10.2307/258887

Erkanawati, S. C. (2018). Pengaruh pengungkapan sustainability report terhadap nilai perusahaan pada perusahaan pertambangan yang terdaftar di bursa efek indonesia pada periode 2011-2015. Parsimonia, 5(1), 83-96.

Evana, E. (2017). The effect of sustainability reporting disclosure based on global reporting initiative (gri) g4 on company performance (a study on companies listed in indonesia stock 
Jurnal Akuntansi Bisnis, Vol. 19, No. 2, September 2021 ISSN 1412-775X (media cetak) | 2541-5204 (media online)

exchange). The Indonesian Journal of Accounting Research, 20(3), 417-442. https://doi.org/10.33312/ijar.394

Faqir, A. Al. (2019, December 16). Pemerintah temukan penyelewengan dana csr garuda indonesia rp50 juta untuk ikagi halaman | merdeka.com. Merdeka.Com. https://www.merdeka.com/uang/pemerintah-temukan-penyelewengan-dana-csr-garudaindonesia-rp-50-juta-untuk-ikagi.html?page $=2$

GRI Standards. (2018). GRI-standards bahasa indonesia translations. https://www.globalreporting.org/how-to-use-the-gri-standards/gri-standards-bahasa-indonesiatranslations/

Handoyo. (2021, June 14). Pertamina mencatatkan penurunan kinerja keuangan sepanjang tahun 2020. Industri.Kontan.Co.Id. https://industri.kontan.co.id/news/pertamina-mencatatkanpenurunan-kinerja-keuangan-sepanjang-tahun-2020

Hardi, E., \& Chairina, C. (2019). The effect of sustainibility reporting disclosure and its impact on companies financial performance. Journal of Wetlands Environmental Management, 7(1), 67. https://doi.org/10.20527/jwem.v7i1.188

Hardiningsih, P., Januarti, I., Yuyetta, E. N. A., Srimindarti, C., \& Udin, U. (2020). The effect of sustainability information disclosure on financial and market performance: empirical evidence from indonesia and malaysia. International Journal of Energy Economics and Policy, 10(2), 1825. https://doi.org/10.32479/ijeep. 8520

Hartini, H., \& Rahayu, D. H. (2018). Pelaksanaan corporate social responsibility (csr) dan kinerja perusahaan manufaktur di indonesia. Media Riset Bisnis \& Manajemen, 18(1), 11. https://doi.org/10.25105/mrbm.v18i1.4991

Hutagalung, A., \& Harahap, K. (2016). Pengaruh pengungkapan sustainability report terhadap profitabilitas perusahaan manufaktur yang terdaftar di bursa efek indonesia periode 2009-2012. Jurnal Akuntansi, Keuangan \& Perpajakan Indonesia, 03(1), 1-14.

Idnfinancials.com. (2020, September 22). Garudafood, indofood, dan wings digugat rp4 miliar karena dinilai merusak lingkungan. Https://Www.Idnfinancials.Com/. https://www.idnfinancials.com/id/news/36290/garudafood-indofood-wings-facing-lawsuitsurabaya

Iswati, W. (2020). The impact of disclosure sustainability reporting, influence corporate social responsibilities towards corporate value with mediation of financial performance. International Journal of Managerial Studies and Research, 8(1), 1-16. https://doi.org/10.20431/23490349.0801001

Kurniawan, A. W., \& Puspitaningtyas, Z. (2016). Metode penelitian kuantitatif. In Philosophy of Science (Vol. 4, Issue 4). Pandiva Buku. 
Jurnal Akuntansi Bisnis, Vol. 19, No. 2, September 2021 ISSN 1412-775X (media cetak) | 2541-5204 (media online)

Laodi, N. (2020, May 25). Ini sektor yang catat kenaikan dan penurunan kinerja pasca laporan kuartal I 2020 - Page 1. Investasi.Kontan.Co.Id. https://investasi.kontan.co.id/news/ini-sektoryang-catat-kenaikan-dan-penurunan-kinerja-pasca-laporan-kuartal-i-2020?page=1

Lestari, N., \& Lelyta, N. (2019). Pengaruh corporate social responsibility terhadap kinerja keuangan. Equity, 22(1), 1. https://doi.org/10.34209/equ.v22i1.897

Liputan6.com. (2020, August 26). Pelaku bisnis perlu didorong terapkan konsep berkelanjutan pascapandemi. News-Liputan6. https://www.liputan6.com/news/read/4340319/pelaku-bisnisperlu-didorong-terapkan-konsep-berkelanjutan-pascapandemi

Marketnews.id. (2021, April 16). Laba bersih pt rukun raharja tbk anjlok 80 persen di 2020. bagaimana kinerja di tahun ini. MarketNews.Id. https://marketnews.id/marketupdate/2021/04/laba-bersih-pt-rukun-raharja-tbk-anjlok-80-persen-di-2020-bagaimana-kinerjadi-tahun-ini/

Natalia, R., \& Tarigan, J. (2014). Pengaruh sustainability reporting terhadap kinerja keuangan perusahaan publik dari sisi profitability ratio. Jurnal Ekonomi, volume 22, 111-120. https://doi.org/10.1017/CBO9781107415324.004

Niar, H. (2019). The impact of decision investment, capital structure and growth on profitability and company value in manufacturing sector of firms in indonesia. International Journal of Accounting \& Finance (IJAFAP), 2(1). https://doi.org/10.32535/ijafap.v2i1.362

Nugrahanti, Y. W., \& Maharani, O. (2013). Karakteristik perusahaan terhadap pengungkapan corporate social responsibility (csr) dan dampaknya terhadap kinerja keuangan. Journal of Management and Business, 12(1), 128-142. https://doi.org/10.24123/jmb.v12i1.14

Odalo, S. K., Achoki, G., \& Njuguna, A. (2016). Relating company size and financial performance in agricultural firms listed in the nairobi securities exchange in kenya. International Journal of Economics and Finance, 8(9), 34. https://doi.org/10.5539/ijef.v8n9p34

Otoritas Jasa Keuangan. (2016, November 2). Undang-undang no. 40 tahun 2007 tentang perseroan terbatas. Www.Ojk.Go.Id. https://www.ojk.go.id/sustainablefinance/id/peraturan/undang-undang/Pages/Undang-Undang-No.-40-tahun-2007-tentangPerseroan-Terbatas.aspx

Pan, X., Sha, J., Zhang, H., \& Ke, W. (2014). Relationship between corporate social responsibility and financial performance in the mineral industry: evidence from chinese mineral firms. Sustainability (Switzerland), 6(7), 4077-4101. https://doi.org/10.3390/su6074077

Prasetyo, W. B. (2020, August 9). Profesional muda didorong jadi penggerak bisnis berkelanjutan. BeritaSatu.Com. https://www.beritasatu.com/whisnu-bagusprasetyo/ekonomi/663593/profesional-muda-didorong-jadi-penggerak-bisnis-berkelanjutan

Puspitandari, J., \& Septiani, A. (2017). Pengaruh sustainability report disclosure terhadap kinerja 
Jurnal Akuntansi Bisnis, Vol. 19, No. 2, September 2021 ISSN 1412-775X (media cetak) | 2541-5204 (media online)

perbankan. Diponegoro Journal Of Accounting, 6(3), 159-170.

Putra, A., \& Badjra, I. (2015). Pengaruhleverage, pertumbuhan penjualan dan ukuran perusahaan terhadap profitabilitas. E-Jurnal Manajemen Universitas Udayana, 4(7), 249411.

Putri, I. G. A. P. T. (2020). Effect of capital structure and sales growth on firm value with profitability as mediation. International Research Journal of Management, IT and Social Sciences, 145-155. https://doi.org/10.21744/irjmis.v7n1.833

Retnosari, R. (2018). Pengaruh dimensi sustainability reporting terhadap kinerja keuangan pada perusahaan yang terdaftar di bursa malaysia. Jurnal Ilmiah Akuntansi Dan Keuangan, 7(1), 6879. https://doi.org/10.32639/jiak.v7i1.269

Rosdwianti, M. K., Dzulkirom, M. A., \& Z.A, Z. (2016). Pengaruh corporate social responsibility (csr) terhadap profitabilitas perusahaan. Jurnal Administrasi Bisnis S1 Universitas Brawijaya, 38(2), 16-22. https://doi.org/administrasibisnis.studentjournal.ub.ac.id 16

Sandria, F. (2021, April 6). Laba adhi anjlok 96\% jadi rp $24 \mathrm{~m}$ di 2020, ini pemicunya. Cnbcindonesia.Com. https://www.cnbcindonesia.com/market/20210406140338-17-235663/labaadhi-anjlok-96-jadi-rp-24-m-di-2020-ini-pemicunya

Saputri, C. K., \& Giovanni, A. (2014). Pengaruh profitabilitas, pertumbuhan perusahaan dan likuiditas terhadap nilai perusahaan. Competence : Journal of Management Studies, 15(1), 90-108.

Sari, I. A. P., \& Andreas, H. H. (2019). Pengaruh pengungkapan sustainability reporting terhadap keuangan perusahaan di indonesia. Jurnal Studi Akuntansi Dan Keuangan, 2(2), 77-90. https://doi.org/10.29303/akurasi.v2i2.16

Sari, P. I. P., \& Abundanti, N. (2014). Leverage terhadap profitabilitas dan nilai perusahaan. EJurnal Manajemen Unud, 3(5), 1427-1441.

Sejati, B. P., \& Prastiwi, A. (2015). Pengaruh pengungkapan sustainability report terhadap kinerja dan nilai perusahaan. Journal Of Accounting, 4(1), 195-206.

Shakil, M. H., Mahmood, N., Tasnia, M., \& Munim, Z. H. (2019). Do environmental, social and governance performance affect the financial performance of banks? a cross-country study of emerging market banks. Management of Environmental Quality: An International Journal, 30(6), 1331-1344. https://doi.org/10.1108/MEQ-08-2018-0155

Soenarso, S. A. (2020, November 9). Hingga kuartal III-2020, laba bersih TOTL turun 40,14\% akibat pandemi Covid-19. Kontan.Co.Id. https://stocksetup.kontan.co.id/news/hingga-kuartal-iii2020-laba-bersih-totl-turun-4014-akibat-pandemi-covid-19

Supriyadi, Sulistiyo, A. B., \& Roziq, A. (2019). Influence disclosure of sustainability report and company size on dividend policy and company value with profitability as intervening variables. International Journal of Scientific and Technology Research, 8(7), 716-721. 
Jurnal Akuntansi Bisnis, Vol. 19, No. 2, September 2021 ISSN 1412-775X (media cetak) | 2541-5204 (media online)

Syafrullah, S., \& Muharam, H. (2017). Analisis pengaruh kinerja environmental, social , dan governance ( esg ) terhadap abnormal return. Ejournal Undip, 6(2), 1-14.

Syamni, G., Wahyuddin, Damanhur, \& Ichsan. (2018). CSR and profitability in idx agricultural subsectors. Emerald Reach Proceedings Series, 1, 511-517. https://doi.org/10.1108/978-1-78756793-1-00034

Tarigan, J., \& Semuel, H. (2014). Pengungkapan sustainability report dan kinerja keuangan. Jurnal Akuntansi Dan Keuangan, 16(2), 88-101. https://doi.org/10.9744/jak.16.2.88-101

Velte, P. (2017). Does ESG performance have an impact on financial performance? evidence from germany. Journal of Global Responsibility, 8(2), 169-178. https://doi.org/10.1108/jgr-11-20160029

Widowati, D., Nugrahanti, Y., \& Kristanto, A. B. (2013). Analisis faktor keuangan dan non keuangan yang berpengaruh pada prediksi peringkat obligasi di indonesia. Jurnal Manajemen, 13(1), 35-54.

Yaparto, M., K., Dianne Frisko, S.E., M. A., \& Eriandani, Rizky, S.E., M. A. (2013). Pengaruh corporate social responsibility terhadap kinerja keuangan pada sektor manufaktur yang terdaftar di bursa efek indonesia pada periode 2010-2011. Jurnal Ilmiah Mahasiswa Universitas Surabaya, 2(1). https://doi.org/10.24815/jdab.v3i2.5384

Zhao, C., Guo, Y., Yuan, J., Mu, M., Li, D., Zhou, Y., \& Kang, J. (2018). ESG and corporate financial performance: empirical evidence from china's listed power generation companies. Journal of Sustainability, 10(8), 1-18. https://doi.org/10.3390/su10082607 